\title{
The influence of natural gas additive on the smoke level generated by diesel engines
}

\begin{abstract}
The paper presents the results of investigations performed on a Fiat 1.3 MultiJet engine fueled with natural gas (CNG) and diesel oil. The primary aim was to determine the influence of a small additive of natural gas on the exhaust gas opacity under variable engine operating conditions. The tests were performed for the engine work points n-Mo (engine speed-torque) reproducing the NEDC cycle. The selection of the work points was carried out according to the criterion of greatest share in the NEDC homologation test, covering the entire engine field of work used in the realization of the test on a chassis dynamometer. In the tests, the authors applied different energy shares of natural gas in the range $15-35.6 \%$. The smoke opacity was analyzed in the FSN and mass scales $\left[\mathrm{mg} / \mathrm{m}^{3}\right]$. The results of the investigations may be used in the design of electronic controllers for natural gas engines and in the adaptation engines to CNG fueling.

Keywords: dual fueling, natural gas, natural gas share, opacity
\end{abstract}

\section{Wpływ dodatku gazu ziemnego na zadymienie spalin samochodowego silnika ZS}

W pracy przedstawiono wyniki badań silnika Fiat 1.3 MultiJet zasilanego dwupaliwowo - gazem ziemnym CNG i olejem napędowym. Podstawowym celem badań było określenie wptywu niewielkiego dodatku gazu ziemnego na zadymienie spalin w zmiennych warunkach pracy silnika. Badania przeprowadzono w punktach pracy silnika n-Mo (prędkość obrotowa - moment obrotowy) odwzorowujących test jezdny NEDC. Doboru punktów pomiarowych dokonano wedtug kryterium największego udziału w teście homologacyjnym NEDC, obejmujacych całe pole pracy silnika wykorzystywane przy realizacji testu wykonywanego na hamowni podwoziowej. W badaniach stosowano różne udziaty energetyczne gazu w zakresie 15-35,6\%. Analizowano zadymienie spalin w skali FSN i masowej [mg/m³]. Wyniki badań moga być wykorzystane przy budowie elektronicznych sterowników silników gazowych i adaptacjach silnika do zasilania CNG.

Słowa kluczowe: dwupaliwowe zasilanie, gaz ziemny, udział gazu, zadymienie spalin

\section{Introduction}

Modern diesel engines are state-of-the-art supercharged units fitted with hi-tech fuel and control systems. The injection of fuel is most frequently realized with a common rail system with multiple injection and variable injection pressure. This allows realization of a controlled course of combustion optimized according to a variety of criteria, the most important of which are the emission level and fuel economy. Despite the application of modern technical design solutions and electronic control, the designers of modern diesel engines still struggle with the problem of exhaust emissions. This is particularly the case for nitrogen oxides $\left(\mathrm{NO}_{\mathrm{x}}\right)$ and particulate mater $(\mathrm{PM})$. These factors limit further development of diesel engines and their maximum operating parameters, particularly those of small displacement. It is noteworthy that the need to meet the Euro VI emission requirements significantly increases the costs of engine production and maintenance, which has an adverse effect on the sales figures. It is a common belief that diesel engines are a good solution only if high annual mileage and extra urban operation is planned.

A recent problem related to diesel engines has been the emission of particulate matter, which, due to its hygroscopy and low density compared to air, is hazardous for the envi-

\section{Wstęp}

Współczesne silniki samochodowe o zapłonie samoczynnym są nowoczesnymi jednostkami wysokodoładowanymi wyposażonymi w najnowocześniejsze układy zasilania i sterowania. Do wtrysku oleju napędowego najczęściej wykorzystywany jest układ wysokociśnieniowy typu common rail z podziałem dawki i zmiennym ciśnieniem wtrysku. Pozwala to realizować tzw. sterowany przebieg spalania optymalizowany według różnorodnych kryteriów, z których najważniejszymi są ekologiczność i ekonomia pracy. Mimo zastosowania najnowocześniejszych osiągnięć technologicznych, konstrukcyjnych i elektronicznego sterowania, konstruktorzy współczesnych silników o zapłonie samoczynnym borykają się ciągle z problemami spełniania zaostrzanych wymogów w zakresie toksyczności spalin. Dotyczy to w przede wszystkim emisji tlenków azotu $\mathrm{NO}_{\mathrm{x}}$ i cząstek stałych PM. Czynniki te ograniczają obecnie dalszy rozwój samochodowych silników o zapłonie samoczynnym i ich maksymalnych parametrów użytkowych, zwłaszcza tych o małych pojemnościach skokowych. Warto przy tym zaznaczyć, że konieczność spełnienia norm toksyczności spalin w zakresie Euro VI bardzo zwiększa koszty wytwarzania i eksploatacji silników ZS, co niekorzystnie wpływa na zainteresowanie nimi ich potencjalnych użytkowników. 
ronment $[2,3,5,7-9,11]$. For this reason the emission of particulate matter has recently been the most highly limited exhaust component. It is noteworthy that not only the mass emission (PM) but also the total number of particles (PN) of increasingly smaller diameter is subject to limitation [7-9]. This requires the application of DPF filters in the exhaust systems trapping the particles of very small diameters, which generates significant flow resistance and forces frequent regeneration. Under non-steady city traffic conditions, during short trips under low temperatures, the DPF filters pose serious operational problems and are thus frequently illegally removed from the vehicles in Poland (as confirmed in the classifieds dealing with this type of services). Vehicles with removed DPF filters do not comply with the emission standards, not only in terms of emission of particulate matter but other exhaust components.

The basic component of particulate matter and its carrier is soot formed as a consequence of thermal cracking of higher hydrocarbons contained in diesel oil, oxidized in rich flame zones with oxygen deficiency $[5,12]$. One of the ways to reduce the emissions of particulate matter is the use of additives of oxygen compounds in the diesel oil [5] or the application of light fuel such as natural gas or pure methane $[6,11,12]$. Compressed natural gas appears to be a particularly significant option because of its low price (for decades the price has been twice as low compared to crude oil-based fuels worldwide) and a high content of methane $\left(94-96 \%{ }_{\text {Vol. }}\right)$.

Methane $\mathrm{CH}_{4}$, the main component of natural gas, is the simplest hydrocarbon containing a single atom of carbon. It is characterized by a simple mechanism of oxidation and good diffusion in air, thanks to which, during combustion with oxygen deficiency soot particles do not form [12]. We may thus assume that the addition of natural gas reduces the smoke level depending on the gas share in the total energy fed to the engine.

Due to high self-ignition temperature of natural gas, however, it still requires an external source of ignition a spark ignition system, or is dependent on the self-ignition of the diesel oil dose - dual fuel system $[1,11,12]$. Due to high compression ratios applied in small diesel engines, the spark ignition system requires extensive design modifications to the engines, which in the transient period of insufficient number of CNG filling stations, remains unsubstantiated. It is, however, possible to fit a system of injection of CNG gas in the vicinity of the intake valves and adapt a diesel engine to dual fueling at a low cost $[1,4,6,11,12]$. We need to remember that maintaining high compression ratio may prevent the application of high share of natural gas in the fuel (knock combustion).

This paper presents the influence of the $\mathrm{CNG}$ additive in the fuel of a Fiat 1.3 MultiJet on the smoke level under variable engine loads and speeds corresponding to the NEDC test.

\section{Test stand}

The tests were performed on a serially manufactured diesel engine (FIAT 1.3 MJT) adapted for dual fueling in the
Istnieje powszechny pogląd, że silniki ZS opłacalne są jedynie przy dużych przebiegach rocznych i przewadze eksploatacji pozamiejskiej.

$\mathrm{W}$ ostatnich latach istotnym problemem dotyczącym silników ZS jest emisja cząstek stałych PM, które ze względu na swoją higroskopijność i małą gęstość w stosunku do powietrza są dużym zagrożeniem dla środowiska $[2,3,5,7-9,11]$. Z tego powodu w ostatnich latach emisja PM była najbardziej ograniczana w porównaniu do innych składników toksycznych spalin. Warto dodać, że ograniczeniom podlega nie tylko masowa emisja PM, ale również całkowita liczba cząstek N, przy czym analizie poddawana jest coraz mniejsza średnica cząstek [7-9]. Wymaga to stosowania w układach wylotowych filtrów cząstek stałych DPF wychwytujących cząstki o bardzo małych rozmiarach, stwarzających w eksploatacji istotne opory przepływu i podlegających częstemu oczyszczaniu. W nieustalonych warunkach miejskich, przy krótkich przebiegach i eksploatacji w niskich temperaturach filtry DPF stwarzają znaczne trudności eksploatacyjne i w warunkach krajowych, niestety, są często usuwane, o czym świadczą liczne ogłoszenia firm zajmujących się takimi usługami. Samochody pozbawione w ten sposób filtrów DPF nie spełniają norm toksyczności nie tylko w zakresie cząstek stałych, ale również innych składników toksycznych.

Zasadniczym składnikiem cząstek stałych i ich nośnikiem jest sadza powstająca w wyniku termicznego krakingu wyższych węglowodorów wchodzących w skład oleju napędowego, utlenianych w bogatych strefach płomienia, głównie przy niedoborze tlenu [5, 12]. Jednym ze sposobów zmniejszenia emisji PM mogą być domieszki związków tlenowych do oleju napędowego [5] lub zastosowanie paliwa lekkiego, przykładowo gazu ziemnego lub czystego metanu $[6,11,12]$. Szczególnie znaczący wydaje się przy tym gaz ziemny sprężony ze względu na niską cenę (od wielu dekad na całym świecie ponad dwukrotnie niższą w stosunku do paliw ropopochodnych), posiadający dużą zawartość metanu $94-96 \%{ }_{\text {Vol }}$.

Metan $\mathrm{CH}_{4}$, główny składnik palny gazu ziemnego, jest najprostszym węglowodorem zawierającym w swej cząsteczce jeden atom węgla. Charakteryzuje się prostym mechanizmem utleniania i dobrą dyfuzją w powietrzu, dzięki czemu podczas jego spalania nawet przy niedoborze tlenu nie powstają cząsteczki sadzy [12]. Można zatem zakładać, że dodatek gazu ziemnego zmniejsza zadymienie spalin zależne od udziału gazu w całkowitej dawce energii podawanej do silnika.

Z uwagi na wysoką temperaturę samozapłonu gaz ziemny wymaga jednak inicjacji zapłonu z obcego źródła system z zapłonem iskrowym, lub od samozapłonu dawki oleju napędowego - system dwupaliwowy $[1,11,12]$. Ze względu na wysokie stopnie sprężania stosowane w małych samochodowych silnikach ZS, system z zapłonem iskrowym wymaga istotnych zmian konstrukcyjnych silnika, co w okresie przejściowym przy niedoborze stacji tankowania CNG jest nieuzasadnione. Można jednak na silnikach instalować układ wtrysku sprężonego gazu CNG w okolice 
Chair of Combustion Engines of University of Bielsko-Biała. The Fiat 1.3 MJT engine is a four-cylinder inline unit of the displacement of $1248 \mathrm{~cm}^{3}$. The engine has been fitted with a direct high-pressure injection common rail system of the second generation based on multiple injection technology (MultiJet). The division of the injection into phases enables the realization of a controlled combustion process, which reduces the noise level, exhaust emissions and improves usable parameters. The engine control unit continuously adapts the fuel dose division pattern, the number of fuel doses and the amount of fuel per cycle for each cylinder. The engine is Euro 4 compliant, not fitted with a DPF [15]. The technical specifications have been shown in Table 1.

Table 1. Technical specifications of the Fiat 1.3 MJT engine Tabela 1. Dane techniczne silnika Fiat 1.3 MJT

\begin{tabular}{|l|c|}
\hline Engine type/typ silnika & $1.3 \mathrm{MJT}$ \\
\hline Bore x stroke/średnica x skok tloka & $69.6 \times 82 \mathrm{~mm}$ \\
\hline Displacement/pojemność skokowa & $1248 \mathrm{~cm}^{3}$ \\
\hline Number of cylinders/liczba cylindrów & 4 \\
\hline Cylinder arrangement/uktad cylindrów & straight/rzędowy \\
\hline Compression ratio/stopień sprężania & 18 \\
\hline Maximum power/moc maksymalna & $51 \mathrm{~kW} @ 4000 \mathrm{rpm}$ \\
\hline Maximum torque/moment maksymalny & $180 \mathrm{Nm} \mathrm{@1750} \mathrm{rpm}$ \\
\hline Injection system/układ wtryskowy & common rail \\
\hline $\begin{array}{l}\text { Number of valves per cylinder/liczba zawo- } \\
\text { rów na cylinder }\end{array}$ & 4 \\
\hline Timing system/typ rozrząu & DOHC \\
\hline $\begin{array}{l}\text { Exhaust gas recirculation/system recyrku- } \\
\text { lacji spalin }\end{array}$ & EGR valve/zawór EGR \\
\hline
\end{tabular}

In the performed investigations and engine adaptation, CNG fueling is treated as complimentary. This means that the gas does not fully replace diesel oil, as is in the case of gasoline engine adaptation for LPG fueling. In dual fuel engines under road conditions, the limiting of the diesel fuel dose is carried out via proper fuel pressure or accelerator pedal position emulators. This results in a reduction of the torque resulting from the injection of diesel oil. In order to maintain the engine load, replacement fuel is fed (injection of natural gas in proper amount). As a consequence, the initial engine characteristics (from the point of view of the engine power) is restored as if diesel oil was the sole fuel.

For the engine adaptation, the authors used a sequential injection system (Oscar-N Diesel SAS by EuropeGAS) [13, 14]. It can operate with any type of diesel engine, irrespective of the number of cylinders, their arrangement, method of air feed or type of fuel injection system. The system can also operate with CNG and LPG upon necessary modifications.

The engine adaptation was based on developing of a prototype intake manifold and installation of additional ducts (coolant, gas, air) and electrical harnesses connecting the $\mathrm{CNG}$ components to the existing system. Gas injectors, gaseous fuel rail and gaseous fuel lines connecting the injectors with the channels of the intake valves in individual cylinders zaworów dolotowych i przy niewielkich kosztach tych instalacji przystosować silnik ZS do zasilania dwupaliwowego $[1,4,6,11,12]$. Należy jednak mieć na względzie, że zachowanie wysokiego stopnia sprężania może uniemożliwić zastosowanie dużego udziału gazu ze względu na zjawisko spalania stukowego.

W tej pracy przedstawiono wpływ dodatku CNG do samochodowego silnika Fiat 1.3 MultiJet na jego zadymienie spalin w zmiennych warunkach obciążenia i prędkości obrotowych odpowiadających warunkom pracy silnika podczas wykonywania testu NEDC.

\section{Stanowisko badawcze}

W badaniach wykorzystywano seryjny silnik o zapłonie samoczynnym FIAT 1.3 MJT adaptowany w Katedrze Silników Spalinowych i Pojazdów ATH w Bielsku-Białej do zasilania dwupaliwowego. Silnik Fiat 1.3 MJT jest 4-cylindrową jednostką w układzie rzędowym, o pojemności skokowej $1248 \mathrm{~cm}^{3}$. W silniku zastosowano bezpośredni, wysokociśnieniowy wtrysk paliwa common rail drugiej generacji, wyposażony w system wielokrotnego wtrysku, tzw. MultiJet. Podział wtrysku na kilka faz umożliwia realizację kontrolowanego procesu spalania, co zmniejsza hałaśliwość i emisję szkodliwych substancji oraz poprawia parametry użytkowe. Sterownik silnika dostosowuje w sposób ciągły schemat podziału, ilość wtryskiwanych dawek oraz ilość dostarczanego paliwa na cykl, dla każdego cylindra. Silnik spełnia limity emisji normy Euro 4, bez stosowania filtra cząstek stałych [15]. Dane techniczne silnika przedstawiono w tabeli 1.

W przeprowadzonych badaniach i adaptacji silnika zasilanie CNG traktuje się jako zasilanie paliwem uzupełniającym. Oznacza to, że gaz nie zastępuje w całości paliwa, jak przy adaptacji silników benzynowych do zasilania gazem. W warunkach trakcyjnych dwupaliwowych silników ZS ograniczenie dawki oleju napędowego uzyskuje się zwykle za pomocą odpowiednich emulatorów (ciśnienia wtryskiwanego paliwa i/lub położenia pedału gazu). Powoduje to redukcję momentu obrotowego silnika wynikającego z wtrysku oleju napędowego. W celu utrzymania bieżącego obciążenia silnika dozuje się paliwo zastępcze w formie wtrysku odpowiedniej ilości gazu. W rezultacie prowadzi to do przywrócenia pierwotnej, z punktu widzenia mocy, charakterystyki silnika (takiej, jak przy zasilaniu wyłącznie olejem napędowym).

Do adaptacji silnika wykorzystano zestaw sekwencyjnego wtrysku gazu Oscar-N Diesel SAS oferowany przez firmę EuropeGAS [13, 14]. Umożliwia on współpracę z każdym rodzajem silnika o zapłonie samoczynnym, niezależnie od liczby cylindrów, ich układu, sposobu doprowadzania powietrza czy systemu wtrysku paliwa. Ponadto system ten umożliwia pracę silnika zasilanego gazem ziemnym CNG lub gazem LPG po zastosowaniu odpowiednich elementów składowych.

Adaptacja silnika sprowadzała się do wykonania prototypowego kolektora dolotowego i instalacji dodatkowych przewodów (płyn chłodzący, gaz, powietrze) i przewo- 
a)

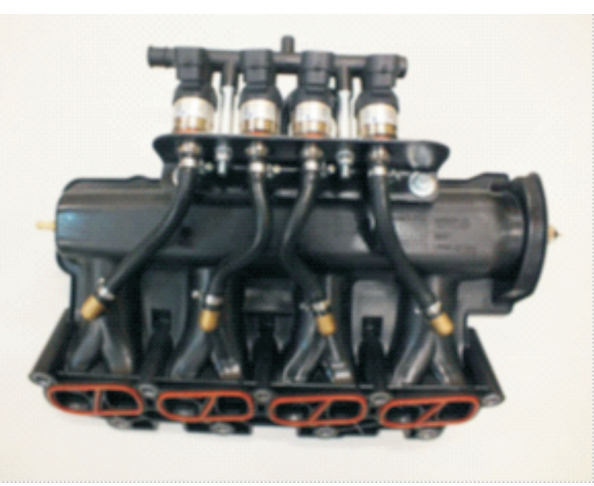

b)

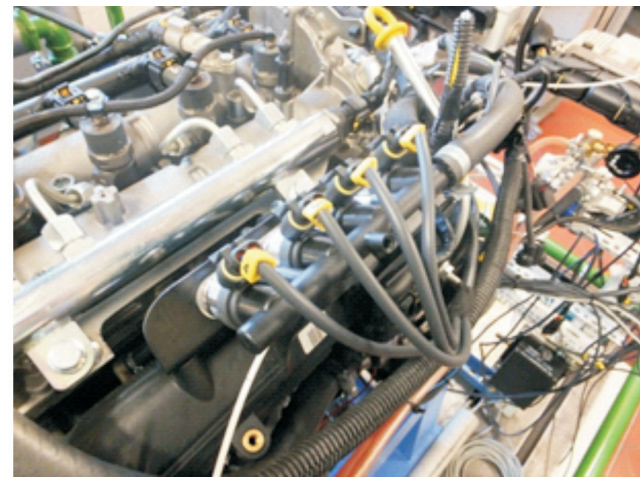

Fig. 1. Intake manifold of the Fiat 1.3 MJT engine with the gas injectors: a) before fitting, b) fitted in the engine Rys. 1. Kolektor dolotowy silnika Fiat 1.3 MJT z wtryskiwaczami gazu: a) kolektor przed montażem, b) kolektor po zamontowaniu

were fitted in the intake manifold, which also included the calibrated injection nozzles at the end of the fuel lines. The prototype intake manifold has been shown in Fig. 1.

The gas fuel system utilized the Hana H2000 injectors with replaceable nozzles feeding gas to the manifold. The gas flow rate was selected to ensure exclusive $\mathrm{CNG}$ fueling in the entire field of work. It is noteworthy that the fitting of the prototype manifold does not enlarge the external dimensions of the engine, which should be an advantage when fitting dual fuel engines in vehicles of different types and makes. The adaptation of the manifold is not technically difficult and may be performed by CNG certified workshops of medium technical level.

Figure 2 presents the test stand of the FIAT 1.3 MJT dual fuel engine $(\mathrm{CNG})$. For the measurement of the smoke level, a modern AVL 415 SE device was used. The result of the measurements is given in FSN (filter smoke number) determined according to ISO and soot concentration in $\left[\mathrm{mg} / \mathrm{m}^{3}\right]$. The measurement range of the device is 0 to 10 FSN. The smoke meter is connected to the controlling computer via Ethernet.

\section{Research methodology and selection of measurement points}

An important parameter in the assessment of modern vehicle engines is the measurement of exhaust emissions under actual traffic conditions i.e. at variable engine speeds, loads and time. In European countries, such investigations are performed on a chassis dynamometer, according to the NEDC cycle procedure. In the performed tests, the authors relied on their earlier experience (Chair of Combustion Engines and Vehicles and of University of BielskoBiała) related to the transposition of motion parameters such as speed and time to corresponding engine parameters such as engine speed and torque described in detail in [10]. When selecting individual measure-

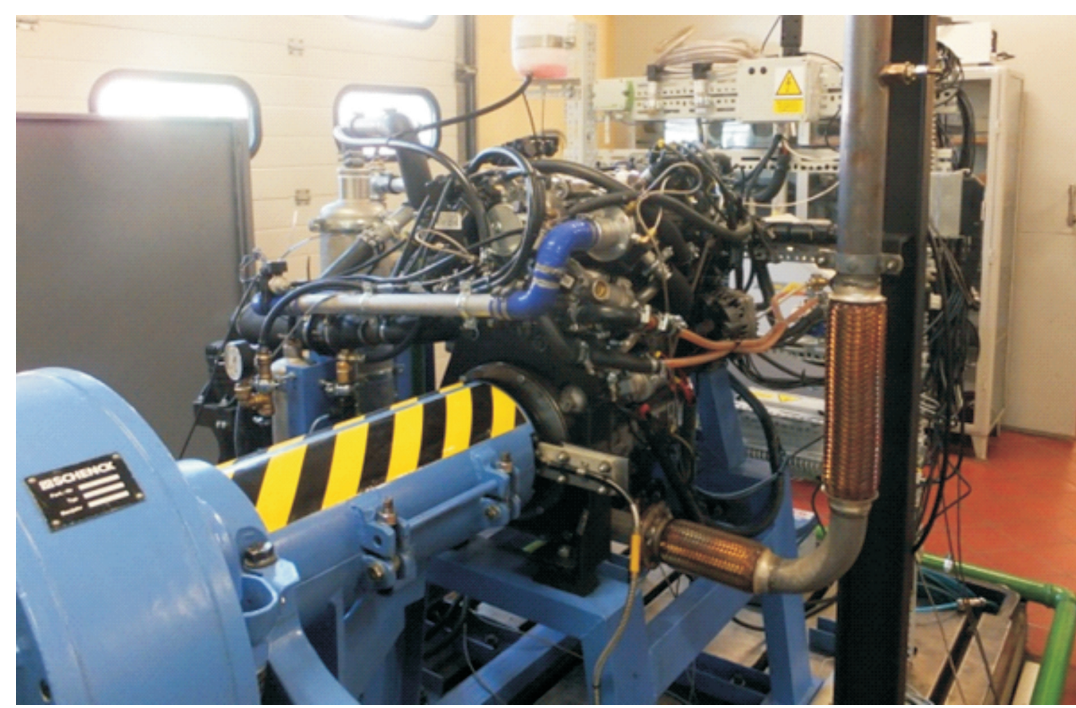

Fig. 2. Engine (FIAT 1.3 MJT) test stands Rys. 2. Stanowisko badawcze silnika FIAT 1,3 MJT 
Table 2. Selected engine work points [10]

Tabela 2. Wytypowane punkty pracy silnika [10]

\begin{tabular}{|c|c|c|c|}
\hline $\begin{array}{l}\text { Number/ } \\
\text { numer }\end{array}$ & $\begin{array}{l}\text { Engine speed/ } \\
\text { prędkość } \\
\text { obrotowa }[\mathrm{rpm}]\end{array}$ & $\begin{array}{c}\text { Torque } / \text { mo- } \\
\text { ment obrotowy } \\
{[\mathrm{N} \cdot \mathrm{m}]}\end{array}$ & $\begin{array}{c}\text { Vehicle speed/ } \\
\text { prędkość } \\
\text { jazdy }[\mathrm{km} / \mathrm{h}] / \text { gear/bieg }\end{array}$ \\
\hline 1 & 820 & 45 & - \\
\hline 2 & 850 & 20 & - \\
\hline 3 & 1050 & 15 & - \\
\hline 4 & 1250 & 20 & - \\
\hline 5 & 1400 & 40 & - \\
\hline 6 & 1550 & 4 & 35/III \\
\hline 7 & 1590 & 10 & $50 / \mathrm{IV}$ \\
\hline 8 & 1650 & 37 & - \\
\hline 9 & 1730 & 11 & $70 / \mathrm{V}$ \\
\hline 10 & 1740 & 26 & - \\
\hline 11 & 1800 & 38 & - \\
\hline 12 & 1920 & 3 & $15 / \mathrm{I}$ \\
\hline 13 & 2050 & 26 & - \\
\hline 14 & 2200 & 4 & 50/III \\
\hline 15 & 2260 & 4 & $32 / \mathrm{II}$ \\
\hline 16 & 2400 & 55 & - \\
\hline 17 & 2500 & 34 & $100 / \mathrm{V}$ \\
\hline 18 & 2700 & 73 & - \\
\hline 19 & 2930 & 80 & - \\
\hline 20 & 3020 & 55 & $120 / \mathrm{V}$ \\
\hline
\end{tabular}

ment points $\mathrm{n}-\mathrm{Mo}$, the criterion of longest engine operating time in reproducing NEDC was applied and the criterion of influence of a measurement point on the results of total emissions in the test. The results of the actual and theoretical tests were processed statistically with dedicated software and a specially developed spreadsheet [10]. The statistical analy-

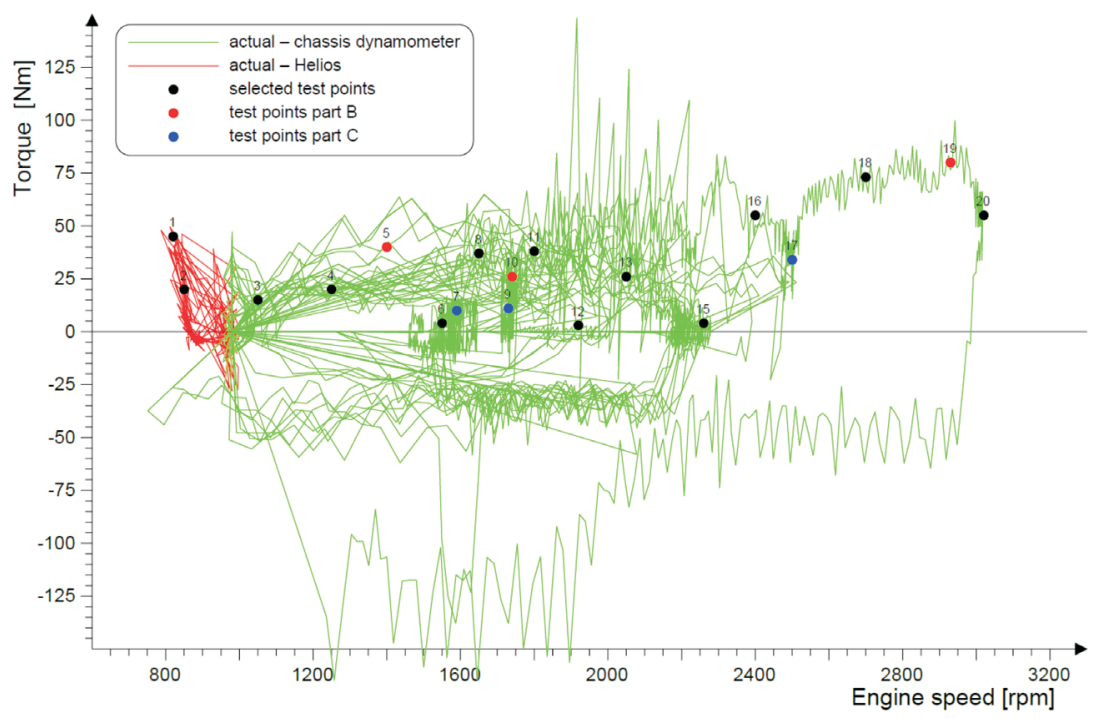

Fig. 3. Selected test points for the driving tests [10]: actual - chassis dynamometer, actual - Helios, selected test points, test points part B, test points part $\mathrm{C}$

Rys. 3. Wytypowane punkty badawcze na tle testu jezdnego [10]

\section{Metodyka badań i dobór punktów pomiarowych}

Istotnym parametrem oceny współczesnych silników samochodowych jest pomiar emisji toksycznych składników spalin w warunkach odpowiadających drogowej eksploatacji, tj. przy zmiennej prędkości obrotowej, obciążeniu i czasie. Badania takie przeprowadza się na hamowni podwoziowej, w krajach europejskich według cyklu NEDC. W przeprowadzonych badaniach wykorzystano wcześniejsze doświadczenia Katedry Silników Spalinowych i Pojazdów ATH związane z przeniesieniem parametrów ruchu samochodu (prędkość - czas) na odpowiednie parametry pracy silnika (prędkość obrotowa - moment obrotowy) opisane szczegółowo w pracy [10]. Przy doborze poszczególnych punktów pomiarowych n-Mo kierowano się kryterium najdłuższego czasu pracy silnika przy odwzorowaniu testu NEDC oraz wpływu punktu pomiarowego na wyniki całkowitej emisji w teście. Wyniki testu rzeczywistego i teoretycznego poddano obróbce statycznej przy użyciu specjalnego programu oraz opracowanego arkusza kalkulacyjnego [10]. Analiza statystyczna posłużyła do wytypowania punktów pracy silnika najbardziej charakterystycznych dla testu jezdnego.

Dla badanego silnika wytypowano ogółem 20 punktów odpowiadających zarówno zmiennej, jak i stałej prędkości jazdy - tab. 2. Na rysunku 3 przedstawiono wytypowane punkty na tle rzeczywistego przebiegu pracy silnika na hamowni podwoziowej podczas wykonywania testu NEDC. Punkty pracy silnika o numerach 6, 7, 9, 12, 14, 15, 17 i 20 mają największy udział w teście i odpowiadają fazom testu ze stałą prędkością jazdy.

\section{Analiza wyników badań}

Porównanie zadymienia spalin przy zasilaniu tradycyjnym i dwupaliwowym graficznie przedstawiono na rys. 4 i 5. W badaniach stosowano fabryczny sterownik silnika i dwa czasy otwarcia wtryskiwaczy gazu $1,5 \mathrm{~ms}$ i 2,0 ms. Dodatek gazu zmniejsza przez sterownik fabryczny dawkę jednostkową oleju, czemu towarzyszy z reguły, szczególnie przy większych obciążeniach silnika, zmniejszenie ciśnienia doładowania i współczynnika nadmiaru powietrza. Powoduje to niekorzystny wpływ na zadymienie spalin i emisję cząstek stałych PM. Widoczne jest to wyraźnie dla punktów 16, 18, 19, dla których obserwowano wzrost zadymienia po dodaniu gazu, szczególnie przy większym jego udziale w ładunku (czas otwarcia wtryskiwacza gazu 2,0 ms). W punktach pracy, w których nie występowało zmniejszenie wydatku powietrza, lub było ono minimalne obserwowano zmniejszenie zadymienia spalin zwiększające się wraz ze wzrostem udziału gazu (środkowe punkty rys. 4 


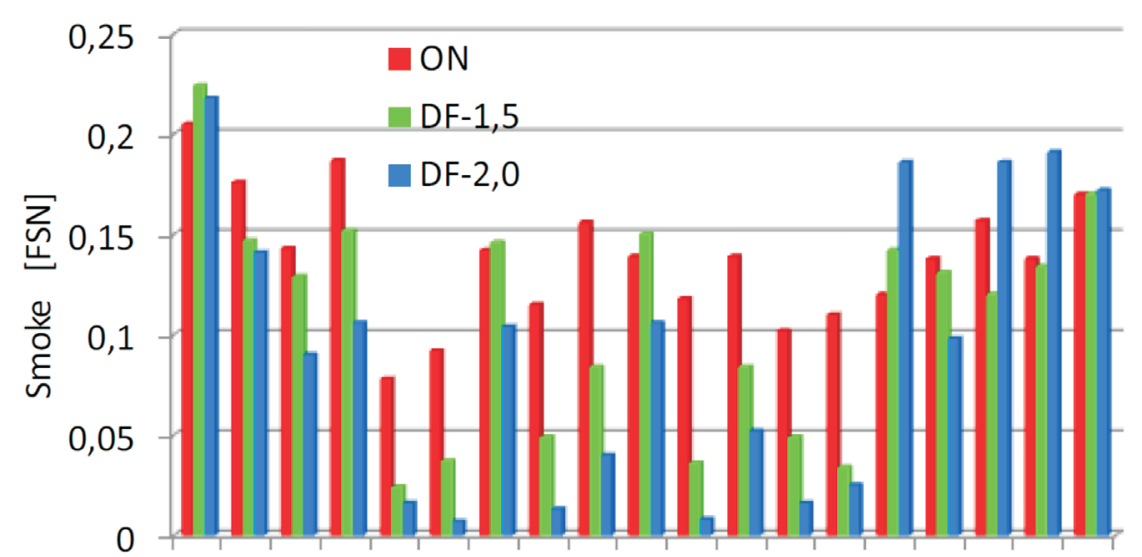

$\begin{array}{lllllllllll}1 & 2 & 3 & 5 & 6 & 7 & 8 & 9 & 1011 & 121314151617181920\end{array}$

Number of operating point according to the test EUDC

Fig. 4. Comparison of the smoke level of the engine fueled with diesel oil and for dual fueling: ON- fueled with diesel oil, DF-1.5 - dual fueling, gas injector opening time $1.5 \mathrm{~ms}$; DF-2.0 - dual fueling, gas injector opening time $2.0 \mathrm{~ms}$

Rys. 4. Porównanie zadymienia spalin silnika zasilanego olejem napędowym i dwupaliwowo: ONzasilanie olejem napędowym, DF-1,5-zasilanie dwupaliwowe, czas otwarcia wtryskiwacza gazu 1,5 ms; DF-2,0 - zasilanie dwupaliwowe, czas otwarcia wtryskiwacza gazu 2,0 ms

ses served the purpose of determining of the work points of the engine most characteristic of the driving tests.

For the tested engine, a total of 20 work points were selected corresponding to both constant and variable vehicle speed - Table 2. In Figure 3 the selected points have been presented against the actual course of engine operation on the chassis dynamometer during the NEDC procedure. The work points $6,7,9,12,14,15,17$ and 20 have the greatest share in the test and correspond to the test phases of constant vehicle speed.

\section{Analysis and results}

The comparison of the smoke level for conventional fueling and dual fueling has been graphically presented in Fig. 4 and 5. During the tests, a factory made engine control unit was applied using two gas injector opening times ( $1.5 \mathrm{~ms}$ and $2.0 \mathrm{~ms})$ The addition of natural gas reduces the diesel oil dose via the engine control unit, which is frequently accompanied by a reduced charging pressure and excess air coefficient (usually at greater engine loads). This has an adverse effect on the smoke level and emission of PM. This is conspicuous for points 16,18 , 19 , for which an increase in the smoke level was observed at greater share of natural gas in the charge (opening time of the injector $-2.0 \mathrm{~ms}$ ). At engine work points at which the reduction of the air volume did not occur or was minimum, a reduced smoke level was observed growing with the increasing share of natural gas in the i 5). Warto przy tym zaznaczyć, że zmianę ciśnienia doładowania, a tym samym ilość jednostkową powietrza w cyklu [ $\mathrm{m}^{3} /$ cykl], monitorowano przez rejestrację parametrów regulacyjnych i rzeczywistych fabrycznego sterownika silnika Fiat 1.3 MultiJet.

Względne zmiany zadymienia spalin przy zasilaniu dwupaliwowym obliczano ze wzoru (1):

gdzie: $\Delta \mathrm{D}$ - względna zmiana zadymienia, $\mathrm{D}_{\mathrm{DF}}$ - zadymienie przy zasilaniu dwupaliwowym dla czasów otwarcia wtryskiwaczy gazu odpowiednio $1,5 \mathrm{~ms}$ i $2,0 \mathrm{~ms}, \mathrm{D}_{\mathrm{ON}}$ - zadymienie spalin silnika zasilanego olejem napędowym.

Zgodnie ze wzorem (1) ujemne wartości $\Delta \mathrm{D}$ oznaczają zmniejszenie zadymienia, dodatnie - jego wzrost. $\mathrm{Z}$ analizy rys. 6 wynika, że dodatek gazu w większości punktów pomiarowych (głównie odpowiadających jeździe miejskiej wg test NEDC) spowodował istotne zmniejszenie zadymienia spalin. Można zatem przypuszczać, że spowoduje to zmniejszenie obciążenia filtra DPF, a tym samym wydłużenie czasu między kolejnymi oczyszczeniami i wzrost jego żywotności. $Z$ uwagi na, sygnalizowaną przez wielu autorów, podwyższoną emisję spalin w trakcie regeneracji filtra PDF wpłynie to również na zmniejszenie emisji innych składników spalin.

Niekorzystną zmianę średniego współczynnika nadmiaru powietrza dla całego ładunku starano się ograniczyć przez ręczną zmianę parametrów regulacyjnych turbosprężarki, tak aby ciśnienia doładowania przy zasilaniu olejem napędowym i dwupaliwowym były możliwie zbliżone. Do tego posłużył specjalny elektroniczny sterownik zbudowany

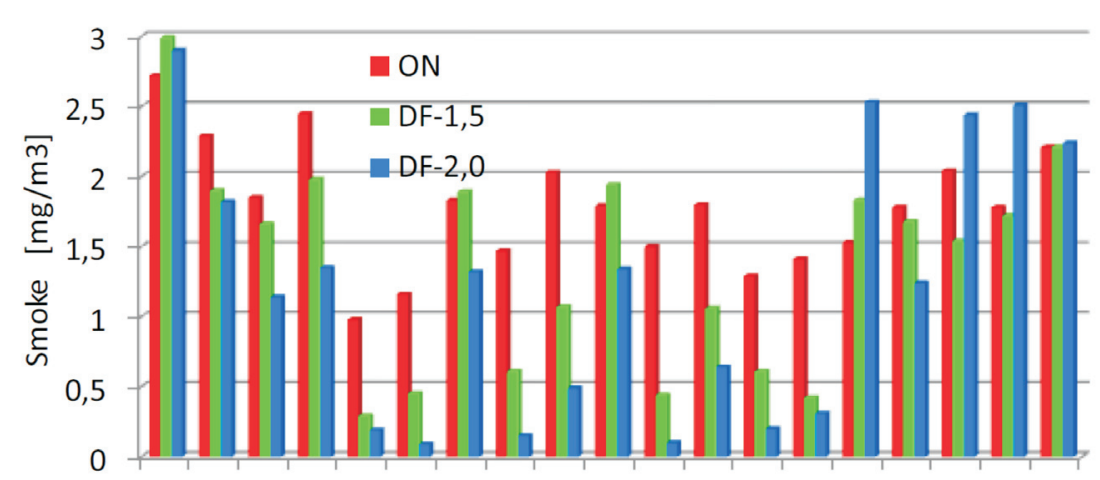

$\begin{array}{lllllllllllllllllll}1 & 2 & 3 & 5 & 6 & 7 & 8 & 9 & 10 & 11 & 12 & 13 & 14 & 15 & 16 & 17 & 18 & 19 & 20\end{array}$ Number of operating point according to the test EUDC

Fig. 5. Comparison of the smoke level of the engine fueled with diesel oil and for dual fueling: ON- fueled with diesel oil, DF-1.5 - dual fueling, gas injector opening time $1.5 \mathrm{~ms}$; DF-2.0 - dual fueling, gas injector opening time $2.0 \mathrm{~ms}$

Rys. 5. Porównanie zadymienia spalin silnika zasilanego olejem napędowym i dwupaliwowo: ONzasilanie olejem napędowym, DF-1,5 - zasilanie dwupaliwowe, czas otwarcia wtryskiwacza gazu 1,5 ms; DF-2,0 - zasilanie dwupaliwowe, czas otwarcia wtryskiwacza gazu 2,0 ms 




Fig. 6. Influence of the gas additive on the change of the smoke level compared to diesel oil fueling for different gas injector opening times: DF-1.5 - dual fueling, gas injector opening time $1.5 \mathrm{~ms}$; DF-2.0 - dual fueling gas injector opening time $2.0 \mathrm{~ms}$

Rys. 6. Wplyw dodatku gazu na zmiany zadymienia spalin $w$ stosunku do zasilania olejem napędowym dla różnych czasów otwarcia wtryskiwacza gazu: DF-1,5-zasilanie dwupaliwowe, czas otwarcia wtryskiwacza gazu 1,5 ms; DF-2,0-zasilanie dwupaliwowe, czas otwarcia wtryskiwacza gazu 2,0 ms

charge (center points in Fig. 4 and 5). It is noteworthy that the change in the charging pressure, hence the unit volume of air in the cycle $\left[\mathrm{m}^{3} /\right.$ cycle] was monitored by recording of the set and actual parameters of the original Fiat 1.3 MultiJet engine control unit.

Relative changes of the smoke level with dual fueling have been calculated from the formula (1):

$$
\Delta \mathrm{D}=100 \cdot \frac{\mathrm{D}_{\mathrm{DF}}-\mathrm{D}_{\mathrm{ON}}}{\mathrm{D}_{\mathrm{ON}}}[\%]
$$

where: $\Delta \mathrm{D}$ - relative change of smoke level, $\mathrm{D}_{\mathrm{DF}}-$ smoke level for dual fueling for the gas injector opening times 1.5 $\mathrm{ms}$ and $2.0 \mathrm{~ms}$ respectively, $\mathrm{D}_{\mathrm{ON}}-$ smoke level for diesel oil fueling.

According to formula (1) negative values of $\Delta \mathrm{D}$ denote a reduction of the smoke level and positive values - its growth. From the analysis of Fig. 6 it results that the gas additive in the majority of measurement points (mainly corresponding to urban driving according to NEDC) caused a reduction of the smoke level. We may thus assume that it will reduce the DPF filter burden, thus extending the DPF regeneration intervals and the DPF life. As indicated by many authors, due to the elevated exhaust emission during the filer regeneration, this will also influence the emission of other exhaust components.

The disadvantageous change of the mean excess air coefficient was reduced by a manual change of the parameters of the turbocharger so that w Katedrze Silników Spalinowych i Pojazdów ATH w Bielsku-Białej.

$\mathrm{Na}$ rysunku 7 przedstawiono graficznie porównanie zadymienia spalin silnika zasilanego dwupaliwowo z czasem otwarcia wtryskiwacza gazu 1,5 ms z regulacją powietrza przez sterownik fabryczny (DF-1,5) oraz z korektą wydatku (DFP1,5). Prawie we wszystkich punktach pomiarowych występuje poprawa zadymienia spalin, szczególnie istotna w punktach pracy silnika pod obciążeniem odpowiadających jeździe pozamiejskiej według testu EUDC. Warto również zaznaczyć, że w niektórych punktach, szczególnie przy silniku pracującym na małych obciążeniach, uzyskano niewielki wzrost zadymienia. Mogło to być spowodowane błędami pomiarów lub niedokładnością regulacji wydatku powietrza, która w tych warunkach pracy silnika jest szczególnie utrudniona.

Również przy zwiększonym udziale gazu (czas otwarcia wtryskiwaczy gazu 2,0 ms) i korekcji wydatku powietrza obserwowano poprawę zadymienia spalin w stosunku do regulacji fabrycznej. Wpływ korekty powietrza zależy jednak od prędkości obrotowej i obciążenia silnika: większy dla większych obciążeń i wyższych prędkości obrotowych (rys. 8).

Wpływ korekty wydatku powietrza na zadymienie spalin można wyraźniej prześledzić na podstawie zmiany względnej zadymienia w stosunku do regulacji fabrycznej obliczonej ze wzoru (2),

gdzie: $\Delta \mathrm{D}_{\mathrm{k}}$ - zmiana zadymienia po korekcie wydatku powietrza, $\mathrm{D}_{\mathrm{DFP}}$ - zasilanie dwupaliwowe $\mathrm{z}$ korektą wydatku powietrza dla czasów otwarcia wtryskiwaczy gazu odpowiednio 1,5 ms i 2,0 ms, $\mathrm{D}_{\mathrm{DF}}$ - zasilanie dwupaliwowe bez korekty wydatku powietrza dla czasów otwarcia wtryskiwaczy gazu 1,5 ms i 2,0 ms.

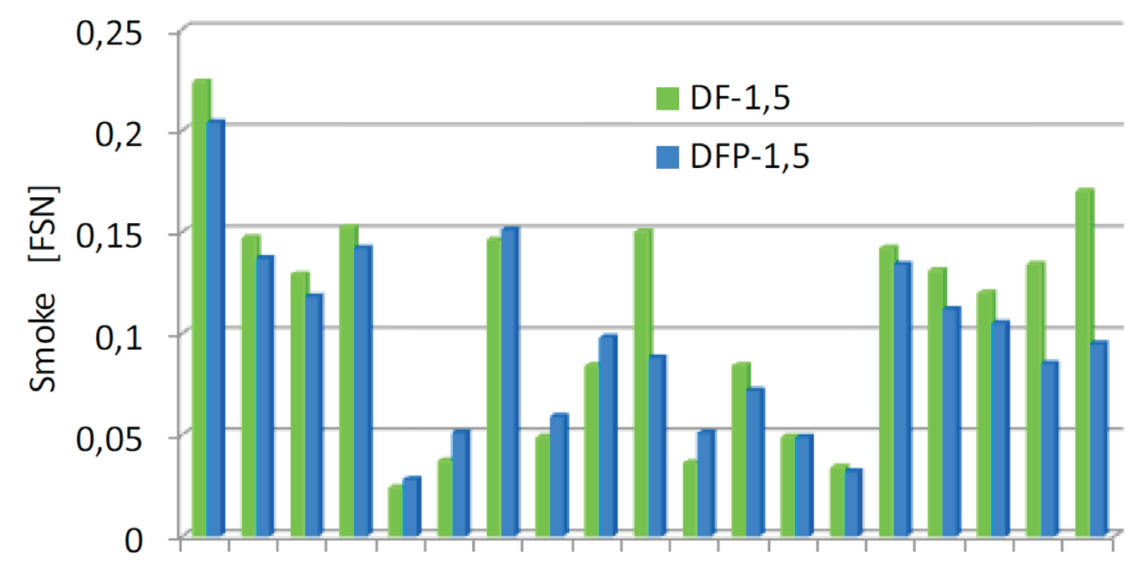

$1 \quad 2 \quad 3 \quad 5 \quad 6 \quad 7 \quad 8 \quad 91011121314151617181920$

Number of operating point according to the test EUDC

Fig. 7. Influence of the air charge rate correction on the smoke level of a dual fuel engine: gas injector opening time $1.5 \mathrm{~ms}$; DF-1.5 - air charge rate adjusted by factory controller, DFP-1.5 - air charge rate correction

Rys. 7. Wplyw korekty wydatku powietrza na zadymienie spalin silnika dwupaliwowego: czas otwarcia wtryskiwaczy gazu 1,5 ms; DF-1,5 - wydatek powietrza regulowany sterownikiem fabrycznym, DFP-1,5 - korekta wydatku powietrza 


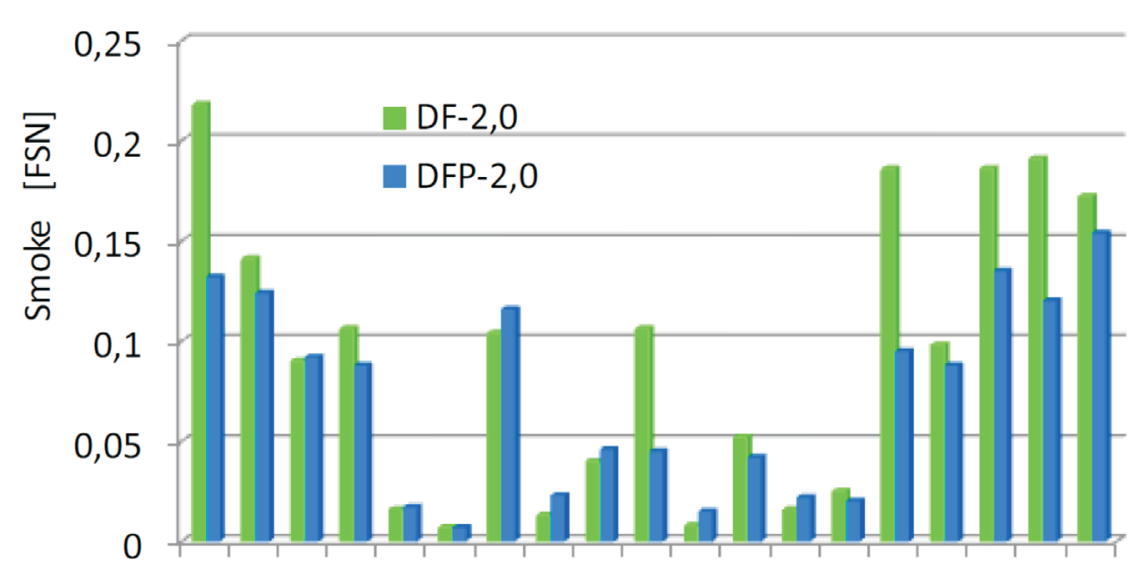

$\begin{array}{llllllllll}1 & 2 & 3 & 5 & 6 & 7 & 8 & 9 & 1011 & 121314151617181920\end{array}$

Number of operating point according to the test EUDC

Fig. 8. Influence of the air charge rate correction on the smoke level of a dual fuel engine: gas injector opening time $2.0 \mathrm{~ms}$; DF-2.0 - air charge rate adjusted by factory controller, DFP-2.0 - air charge rate correction

Rys. 8. Wplyw korekty powietrza na zadymienie spalin silnika dwupaliwowego: czas otwarcia wtryskiwaczy gazu 2,0 ms; DF-2,0 - wydatek powietrza regulowany sterownikiem fabrycznym, DFP-2,0 - korekta wydatku powietrza

the charging pressures when fueled with diesel oil and for dual fueling were similar. For this purpose the authors used a dedicated controller developed at the Chair of Combustion Engines and Vehicles of University of Bielsko-Biała.

Figure 7 presents a comparison of the smoke levels from the engine operating in the dual fueling mode (with the gas injector opening times $1.5 \mathrm{~ms}$ and charge air adjustment by the factory made engine controller - DF-1.5) and in the manual charge air adjustment mode (DFP-1.5). In almost all measurement points, an improvement in the smoke level takes place, which is particularly important at the engine work points under load corresponding to the extra urban driving (EUDC). It is also noteworthy that at some points, particularly for engine under small loads, a low smoke level was obtained. This could have been a result of the measurement error or inaccuracy of the charge air control, which is extremely difficult under such operating conditions.

Also, with the increased natural gas share (gas injector opening time 2.0 $\mathrm{ms}$ ) and the correction of the air charge rate, a reduced smoke level compared to factory adjustment was observed. The influence of the air charge rate correction, however, depends on the engine speed and engine load: it is greater for higher loads and engine speeds (Fig. 8).

The influence of the air charge rate correction on the smoke level can be seen following its relative change against the factory adjustment calculated from the formula:
Zmiany zadymienia spalin pokazane na rys. 9 i 10 wskazują na korzystny wpływ korekty wydatku powietrza, szczególnie przy mniejszym udziale gazu (rys. 9). Istotnej poprawie uległa wartość zadymienia w punktach pomiarowych odpowiadających jeździe pozamiejskiej ze stałą prędkością, gdzie zadymienie uległo zmniejszeniu W zakresie $20-45 \%$. W warunkach tych, przy pracy pod obciążeniem 40-80 N·m silnik emituje znacznie więcej cząstek stałych w stosunku do innych badanych punktów. Równocześnie jednak korekta powietrza w punktach środkowych (rys. 9 i 10) spowodowała zwiększenie zadymienia spalin, co mogło być związane z niedoskonałością sterowania wydatku, o czym wspominano wyżej. W punktach tych jednak zadymienie w warunkach pracy silnika bez korekty powietrza było bardzo małe, co istotnie wpływało na wartość zmiany względnej obliczanej ze wzoru (2).

Mimo mniejszego wpływu korekty wydatku powietrza na zadymienie spalin przy czasach otwarcia wtryskiwaczy gazu 2,0 ms w stosunku do 1,5 ms (co wynika z porównania zadymienia spalin - rys. $10 \mathrm{z}$ rys. 9), należy pokreślić, że z punktu widzenia emisji cząstek stałych korzystniejsze warunki występują przy większych udziałach gazu, kiedy bezwzględne różnice zadymienia w stosunku do oleju napędowego są większe. $Z$ tego powodu na rys. 11 pokazano dla czasu otwarcia wtryskiwaczy 2,0 ms realne możliwości zmniejszenia zadymienia spalin przez dodatek gazu. Udział energetyczny gazu był wtedy w zakresie $24,6-35,6 \%$. Pra-

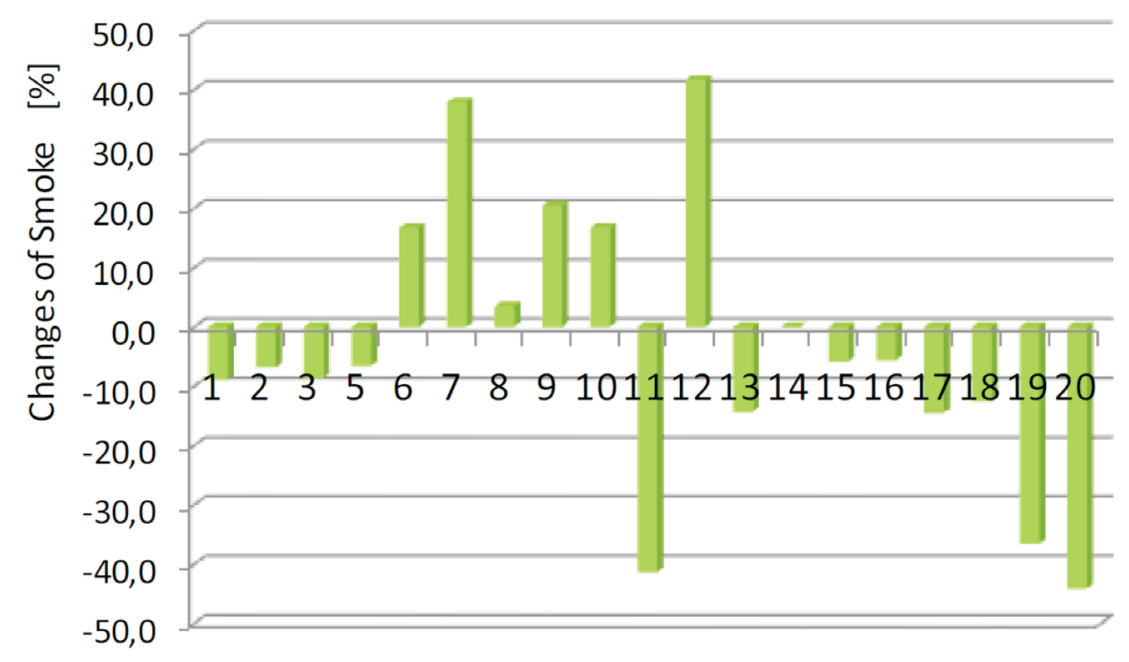

Fig. 9. Influence of the air charge rate correction on the smoke level for the gas injector opening time of $1.5 \mathrm{~ms}$

Rys. 9. Wplyw korekty wydatku powietrza na zadymienie spalin dla czasu otwarcia wtryskiwaczy gazu $1,5 \mathrm{~ms}$ 


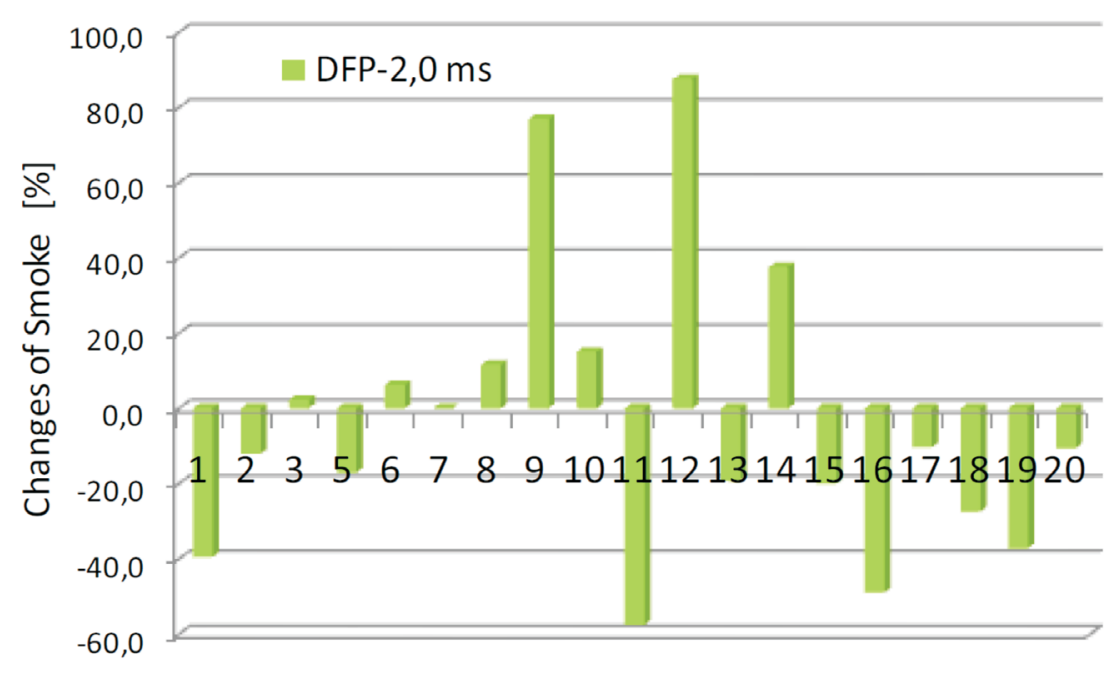

Fig. 10. Influence of the air charge rate correction on the smoke level for the gas injector opening time of $2.0 \mathrm{~ms}$

Rys. 10. Wphyw korekty wydatku powietrza na zadymienie spalin dla czasu otwarcia wtryskiwaczy gazu 2,0 ms

$$
\Delta \mathrm{D}_{\mathrm{k}}=100 \cdot \frac{\mathrm{D}_{\mathrm{DFP}}-\mathrm{D}_{\mathrm{DF}}}{\mathrm{D}_{\mathrm{DF}}}[\%]
$$

where: $\Delta D_{k}$ - change of smoke level upon correction of the air charge rate, $\mathrm{D}_{\mathrm{DFP}}$ - dual fueling with air charge rate correction for gas injector opening times $1.5 \mathrm{~ms}$ and $2.0 \mathrm{~ms}$ respectively, $\mathrm{D}_{\mathrm{DF}}$ - dual fueling without air charge rate correction for gas injector opening times $1.5 \mathrm{~ms}$ and $2.0 \mathrm{~ms}$.

The changes in the smoke level shown in Fig. 9 and 10 indicate a positive influence of the air charge rate correction, particularly for lower natural gas shares (Fig. 9). A significant improvement in the smoke level can be observed at work points corresponding to extra urban driving at constant speeds for which the smoke level was reduced 20-45\%. Under such conditions, under the load of $40-80 \mathrm{~N} \cdot \mathrm{m}$ the engine generated much more particulate matter compared to other work points. At the same time, a single air charge rate correction in the center points (Fig. 9 and 10) resulted in an increase in the smoke level, which may have been related to the inaccuracy of the air charge rate control, as mentioned above. At these points, however, without air charge rate correction the smoke level was very low, which significantly influenced the value of the relative change calculated from the formula (2).

Despite lesser influence of the air charge rate correction on the smoke level for gas injector opening times of $2.0 \mathrm{~ms}$ compared to $1.5 \mathrm{~ms}$ (compare the smoke levels in Fig. 10 and Fig. 9) one needs to emphasize that from wie we wszystkich badanych punktach pomiarowych zadymienie spalin uległo zmniejszeniu. Trzeba jednak zaznaczyć, że wymaga to korekty wydatku powietrza, tak aby współczynnik nadmiaru powietrza był taki sam jak przy zasilaniu tradycyjnym. W praktyce oznacza to konieczność zastosowania specjalnego algorytmu w sterowniku gazu przy zasilaniu dwupaliwowym, który przejmie kontrolę nad współczynnikiem nadmiaru powietrza zamiast sterownika fabrycznego.

Względne zmiany zadymienia w stosunku do oleju napędowego uzyskane w omawianych warunkach udziału gazu 24,6-35,6\% mogą być obliczone ze wzoru (3), gdzie:

$\Delta \mathrm{D}_{\mathrm{kDF}-2,0}$ - względna zmiana zadymienia spalin przy korekcie wydatku powietrza i czasie otwarcia wtryskiwacza gazu 2,0 ms, $\mathrm{D}_{\text {DFP-2,0 }}$ - zadymienie spalin silnika dwupaliwowego przy czasie otwarcia wtryskiwacza gazu 2,0 ms, $\mathrm{D}_{\mathrm{ON}}$ - zadymienie spalin silnika zasilanego olejem napędowym.

Względne zmiany zadymienia (rys. 12) wskazują, że w warunkach jazdy testowej według NEDC możliwe jest zmniejszenie zadymienia spalin we wszystkich badanych punktach, a zmiany względne mieszczą się w zakresie 12 $92 \%$. Z punktu widzenia działania filtra szczególnie istotne jest zmniejszenie w warunkach zwiększonego obciążenia silnika, co pokazano na rys. 13 .



Number of operating point according to the test EUDC

Fig. 11. Comparison of the smoke level from the engine operating in the conventional and dual fuel mode with air charge rate correction: air charge rate level equivalent to the level when fueled with diesel oil, gas injector opening time $2.0 \mathrm{~ms}$

Rys. 11. Porównanie zadymienia spalin silnika zasilanego tradycyjnie i dwupaliwowo z korekta wydatku powietrza: wydatek powietrza przy zasilaniu dwupaliwowym taki sam jak przy zasilaniu olejem napędowym, czas otwarcia wtryskiwaczy gazu 2,0 ms 
the point of view of the emission of particulate matter, better conditions occur if natural gas share is higher (when the absolute differences of the smoke level are higher, compared to exclusive diesel oil fueling). Fig. 11 shows the real possibilities of reduction of the smoke level by natural gas addition for the gas injector opening time of $2.0 \mathrm{~ms}$. The energy share of natural gas was then $24.6-35.6 \%$. For almost all investigated measurement points the smoke level was reduced. It is noteworthy, however, that it required a correction of the air charge rate so that the excess air coefficient remained the same as in the case of conventional fueling. In practice, it is requires a special algorithm controlling the excess air coefficient in the gas control unit for dual fueling that overrides the factory controller.

The relative changes in the smoke level compared to diesel oil fueling obtained for the said gas share of $24.6-35.6 \%$ can be calculated from the formula:

$$
\Delta \mathrm{D}_{\mathrm{kDF}-2.0}=100 \cdot \frac{\mathrm{D}_{\mathrm{DFP}-2.0}-\mathrm{D}_{\mathrm{ON}}}{\mathrm{D}_{\mathrm{ON}}}[\%]
$$

where: $\Delta \mathrm{D}_{\mathrm{kDF}-2.0}$ - relative change of the smoke level with the air charge rate correction and gas injector opening time $2.0 \mathrm{~ms}, \mathrm{D}_{\mathrm{DFP}-2.0}-$ smoke level of the engine operating in the dual fuel mode for the gas injector opening time $2.0 \mathrm{~ms}$, $\mathrm{D}_{\mathrm{ON}}-$ smoke level of an engine fueled exclusively with diesel oil.

The relative changes of the smoke level (Fig. 12) indicate that under the conditions of a NEDC test drive it is possible to reduce the smoke level for all tested work points and the relative changes fall in the range $12-92 \%$. From the point of view of the DPF filter, the reduction is particularly important under the conditions of increased loads, as shown in Fig. 13.

\section{Conclusions}

The application of gas additive in vehicle diesel engines influences the smoke level, i.e. the emission of particulate matter. The influence of the gas additive, however, depends on the method of engine control. The gas additive and the application of the factory engine control $\mathrm{u}$ nit reduce the smoke level at engine points where

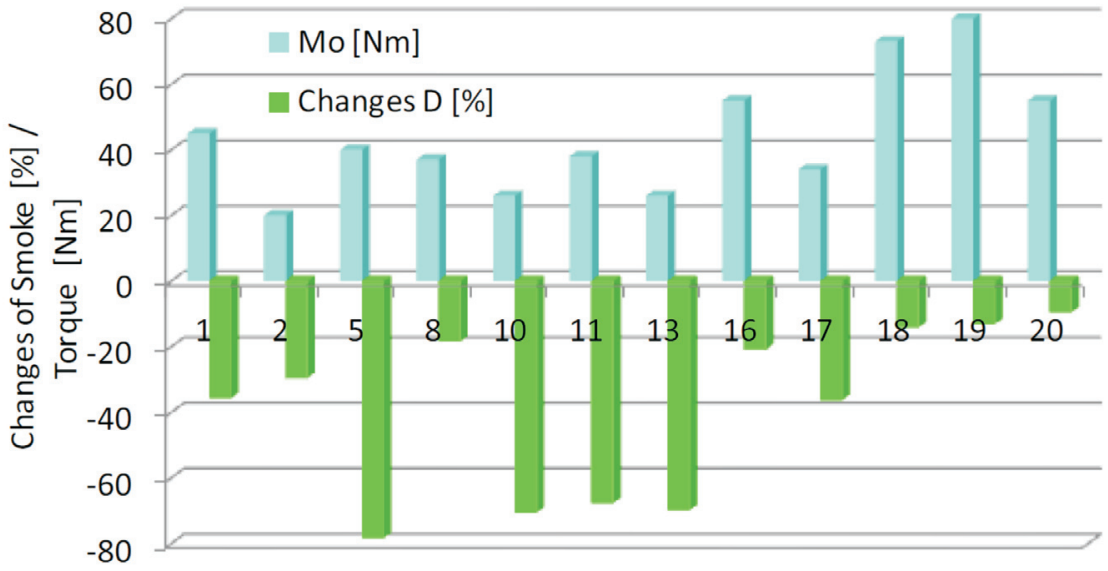

Fig. 13. Relative changes in the smoke level of a dual fuel engine operating at the work points reflecting the NEDC test (Table 2) compared to the engine operating in the diesel fuel only mode: air charge rate correction, gas injector opening time $2.0 \mathrm{~ms}$, energy share of natural gas $24.6-35.6 \%$

Rys. 13. Względne zmiany zadymienia spalin dwupaliwowego silnika pracujacego pod obciązeniem w wybranych punktach odwzorowujacych test NEDC (tab. 2) w stosunku do zasilania samym olejem napędowym: korekta wydatku powietrza, czas otwarcia wtryskiwaczy gazu 2,0 ms, udzial energetyczny gazu 24,6-35,6 
the engine control units does not reduce the excess air coefficient. At work points where the control unit reduces the excess air coefficient, the application of natural gas may lead to an increase in the smoke level. Hence, in dual fuel engines, special engine control units, adapted to dual fueling, must be applied.

The correction of the air charge rate during natural gas fueling allows a radical reduction of the smoke level in the range $30-92 \%$ at small engine loads and $12-40 \%$ at high engine loads.

In engines fitted with DPF under the test conditions, the influence of the gas additive may be smaller. We may suppose that, in actual operation, the positive influence of natural gas on the smoke level will reduce the DPF burden, extend the DPF regeneration intervals and the DPF life. An additional aspect will be reduced exhaust emissions during filter regeneration, as stressed by many authors. wych należy stosować specjalne sterowniki dostosowane do zasilania dwupaliwowego.

Zastosowanie korekty wydatku powietrza przy zasilaniu gazem umożliwia radykalne zmniejszenie zadymienia spalin w zakresie 30-92\% przy niewielkich obciążeniach silnika i $12-40 \%$ przy większych obciążeniach.

W silnikach wyposażonych w filtry cząstek stałych DPF w warunkach badań testowych wpływ dodatku gazu może być znacznie mniejszy dzięki oddziaływaniu filtra DPF. Można jednak przypuszczać, że podczas eksploatacji pozytywne oddziaływanie dodatku gazu na zadymienie spalin znacznie zmniejszy obciążenie filtra DPF, zwiększy okres między cyklami jego oczyszczania i jego żywotność. Dodatkowym aspektem będzie zmniejszona emisja spalin podczas regeneracji filtra, co podkreślane jest przez wielu autorów.

Praca była wykonywana w ramach projektu badawczego nr PBS1/A6/13/2012 pt. „Ograniczenie zadymienia spalin i emisji

cząstek stałych w spalinach samochodowych silników o zapłonie samoczynnym za pomocą dodatku gazu ziemnego CNG” finansowanego przez NCBiR.

\section{Bibliography/Literatura}

[1] Barroso P., Ribas X., Domingues J., De Sella E., Garcia J.M. Study of dual-fuel (diesel+natural gas) particle mater and $\mathrm{CO}_{2}$ emissions of a heavy-duty diesel engine during transient operation. Combustion Engines; 2/2013 (153) ISSN 0138-0346: 28-39.

[2] Clark N.N., Atkinson Chr.M., Atkinson R.J., McDaniel T., Park T. Optimized emission reduction strategies for dual fuel compression ignition engines running on natural gas and diesel. www.cemr.wvu.edu 2002: 1-6.

[3] Gebert K., Beck J., Barkhimer R.L., Wong H.Ch. Strategies to improve combustion and emission characteristics of dual-fuel pilot ignited natural gas engines. SAE Paper 1997; 971712: 79-87.

[4] KowalewiczA. Adaptacja silnika wysokoprężnego do zasilania gazem naturalnym. Czasopismo Techniczne, Wydawnictwo Politechniki Krakowskiej 2008; 7-M/2008: 67-78.

[5] Kozak M. Studium wpływu komponentów tlenowych oleju napędowego na emisję toksycznych składników spalin z silników o zapłonie samoczynnym. Wydawnictwo Politechniki Poznańskiej, Poznań 2013.

Prof. Zdzisław Stelmasiak, DSc., DEng. - Professor in the Faculty of Mechanical Engineering at University of Bielsko-Biala.

Prof. dr hab. inż. Zdzisław Stelmasiak - kierownik Katedry Silników Spalinowych i Pojazdów Akademii Techniczno-Humanistycznej w Bielsku-Białej. e-mail: zstelmasiak@ath.bielsko.pl

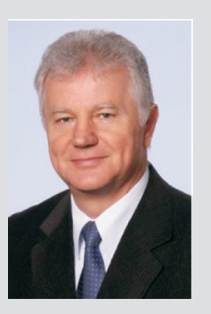

Jerzy Larisch, DEng. - Adiunkt in the Faculty of Mechanical Engineering at University of BielskoBiała.

Dr inż. Jerzy Larisch - adiunkt na Wydziale Budowy Maszyn i Informatyki Akademii Techniczno-Humanistycznej w Bielsku-Białej. e-mail: jlarisch@ath.bielsko.pl

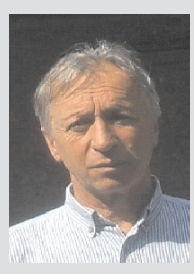

[6] Matyjasik M. Aktywizacja procesu spalania mieszaniny gazpowietrze w silnikach dwupaliwowych przez podział dawki inicjującej oleju napędowego. Praca doktorska, Bielsko-Biała 2012.

[7] Merkisz J., Daszkiewicz P., Idzior M., Bajerlein M., Fuć P., Lijewski P. Analiza ograniczenia emisji toksycznych składników spalin dwupaliwowego silnika o zapłonie samoczynnym. Logistyka, nr 6/2014, s. 7260-7269. p-ISSN: 1231-5478.

[8] Merkisz J., Pielecha J. Emisja cząstek stałych ze źródeł motoryzacyjnych. Wydawnictwo Politechniki Poznańskiej, Poznań 2014.ISBN: 978-83-7775-325-5.

[9] Merkisz J., Pielecha J., Łabędź K., Stojecki A. Badania emisji spalin pojazdów o różnej klasie emisyjnej zasilanych gazem ziemnym. Prace Naukowe Politechniki Warszawskiej. Transport. 2013, z. 98, s. 463-472. Rok: 2013.ISSN: 1230-9265.

[10] Pietras D., Sobieszczański M., Świątek A., Pajdowski P. Dobór parametrów pracy silnika 1.3 multijet charakterystycznych dla testu jezdnego NEDC do badań rozwojowych. PTNSS P05-C065, PTNSS Kongres 2005.

[11] Stelmasiak Z. Studium procesu spalania gazu w dwupaliwowym silniku o zapłonie samoczynnym zasilanym gazem ziemnym i olejem napędowym. Wydawnictwo ATH, BielskoBiała 2003.

[12] Stelmasiak Z. Dwupaliwowe silniki o zapłonie samoczynnym. Wydawnictwo Naukowe Instytutu Technologii Eksploatacji, Biblioteka Problemów Eksploatacji, Radom 2013.

[13] Stelmasiak Z., Larisch J. Dwupaliwowe zasilanie silnika Fiat 1.3 MultiJet. Logistyka 6/2014.

[14] Materiały firmy FIAT AUTO POLAND, 2014.

[15] Materiały techniczne firmy EuropeGAS, 2013.

Dariusz Pietras, DEng. - senior lecturer in the Faculty of Mechanical Engineering at University of Bielsko-Biala.

Dr inż. Dariusz Pietras - st. wykładowca na Wydziale Budowy Maszyn Akademii TechnicznoHumanistycznej w Bielsku-Białej. e-mail:dpietras@ath.bielsko.pl

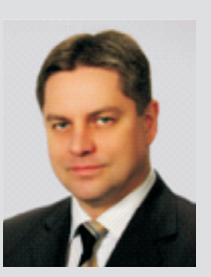

